\title{
ROLE AND PLACE OF TASH-KUMYR SEMICONDUCTOR MATERIALS PLANT IN REGIONAL DEVELOPMENT
}

\author{
CZhumashova G.,Ph.D., Osh State University,Osh, Kyrgyzstan,nilu_56@bk.ru \\ CArstanov S., Ph.D., Osh State University, Osh, Kyrgyzstan
}

\section{РОЛЬ И МЕСТО ТАШ-КУМЫРСКОГО ЗАВОДА ПОЛУПРОВОДНИКОВЫХ МАТЕРИАЛОВ В РЕГИОНАЛЬНОМ РАЗВИТИИ}

\author{
(СЖумашова Г. С., канд. ист. наук., Ошский государственный университет, \\ 2.Ou, Kblpzызстан,nilu_56@bk.ru \\ (САрстанов С. А., канд. ист. наук., Оиский государственный университет, \\ 2. Оu, Кыргызстан
}

Abstract. As for the construction of the Tash-Kumyr semiconductor materials plant, the best mining and metallurgical plant was associated with this plant. Semiconductor materials were used for the development of radio engineering and electrical production, and the construction of this plant in this area was one of the most important priorities of the city's development. In the USSR, the production of semiconductor materials is not very developed. The Soviet government imported a large portion of semiconductor materials from the United States.

Аннотащия. Что касается строительства Таш-Кумырского завода полупроводниковых материалов, то с ним был связан лучший горно-металлургический комбинат. Полупроводниковые материалы использовались для развития радиотехнического и электротехнического производства, и строительство завода в этом районе было одним из важнейших приоритетов развития города. В СССР производство полупроводниковых материалов было не очень развито. Советское правительство импортировало большую часть полупроводниковых материалов из Соединенных Штатов.

Keywords: concept, Kyrgyz Republic, cities, development of small towns, development urban-type settlements, population, territory, economic potential, infrastructure, economics, category.

Ключевые слова: концепция, Кыргызская Республика, города, развитие малых городов, развитие поселков городского типа, население, территория, экономический потенциал, инфраструктура, экономика, категория.

In order to solve this problem, the Politburo of the CPSU Central Committee instructed the Ministry of non-ferrous metallurgy of the USSR to build a powerful plant for the production of semiconductor materials for electrical and radio engineering industries for electric networks. At the same time, as a member of the Politburo of the CPSU Central Committee, Turdaka Usubaliev, after reviewing the minutes of the meeting, after the Minister of non-ferrous metallurgy of the USSR, Pyotr Fadeevich Lomako, made his proposal on the phone, said to Turdak Usubaliev: "no country has asked to build this plant on its territory. We are transferring the development of this event to Kyrgyzstan, and your Republic is responsible for the construction of the plant," he said. After that, 
the Central Committee of the CPSU and the Council Of Ministers of the USSR decided to build a semiconductor materials plant in Tash-Kumyr, Kyrgyz SSR [1, 2].

After reviewing the decision of the Politburo of the CPSU Central Committee on the construction of a semiconductor materials plant in the country, the Minister of non-ferrous metallurgy of the Kyrgyz SSR, L. Kuznetsova, familiarized herself with the decision of the Politburo of the CPSU Central Committee on the construction of a plant for the production of semiconductor materials.Full Name of the Gyz Republic of the proposal and consideration in the Jogorku Kenesh. Lomako's letter, which received a response to this proposal, notes that there are special conditions for launching the plant in Kyrgyzstan [59,315]. As we know, the semiconductor materials plant consumes over 1 million kilowatts / hour of electricity annually. In the Republic, near the city of Tash-Kumyr, on the Naryn river, the Toktogul HPP with a voltage of 1200 thousand kilowatts and three Kurgan HPPs with a voltage of 180 thousand kilowatts operated. Within the Naryn river above these HPPs, with a capacity of 800 thousand kilowatts, the construction of the Kurpsay HPP remains incomplete [3].

In the XI five-year plan, in 1981, the construction of the Tash-Kumyr HPP with a capacity of 450 thousand kilowatts was Started, the total cost of construction is 2.3 million US dollars. the development of the technical and economic foundations of the Kambaratinsk and Shamaldy-Say HPP with a capacity of kilowatts has been started.

The technical project for the construction of the plant was developed and approved in 1982. In 1981, in agreement with the state planning Committee of the USSR, 3 million rubles were provided for the preparatory work for the construction of the plant. For technical and economic construction of the plant in the amount of 342.4 million rubles, for industrial construction-250.4 million US dollars. us $\$ 71$ million has been allocated for the construction of civilian residential buildings. 21 million US dollars for the construction of a production base in the amount of [4] rubles.

In 1981, with the introduction of a semiconductor materials plant, the country allowed the expansion of silicon production at the secondary level with a total capacity of.

The plan XI of the five-year project in 1985 primarily provided for the construction of a semicrystalline silicon plant with a capacity of. The estimated cost of construction in the first place was 183.9 rubles, as well as industrial construction-138 million US dollars. the amount of income tax was 36.3-17 rubles.

In the decision of the main state examination of the state plan of the USSR, expenses included both housing construction objects for developers and the composition of non-production tasks. The plant has a place in the New square and must build in the shortest possible time to put into operation, and in 1981-1985 the estimated cost of construction of houses and the strengthening of social facilities, the total volume cultural buildings amounted to 31 million dollars. funding is provided in the amount of 27.3 rubles.

The Ministry of non-ferrous metallurgy of the USSR and the Central Committee of the Communist party of Kyrgyzstan ask to establish a special order at the semiconductor materials plant in the Kyrgyz SSR, since the plant's products were of special importance in the National economy. When planning and setting of capital were contributed to the Council of Ministers of the USSR of October 20, 1971 No. 2254 [28,17], the distribution of objects of production and non-production purposes, as well as in the destination account total capital loads on building non-production facilities in 1981, attracted 2 million US dollars. sent rubles [5]. 
During this period, the Minister of non-ferrous metallurgy of the SSRF. I. O. Lomako, who, on the basis of order No. 128.3 of February 5, 1981, sent the following directions [3]. The Union center attached great importance to the construction of the plant. The launch and expansion of the plant strengthened the all-Union national economic complex. this production contributed to the socio-economic development of not only the Republic, but also the entire Soviet Union, providing employment and creating thousands of new jobs.

In 1982, with the support of the Ministry of nonferrous metallurgy of the USSR Ministry of construction of the USSR, the State planning Committee of the USSR, Department of state equipment of the USSR on the construction site of the plant were deployed construction work. The Council of Ministers of the USSR and the Central Committee of the CPSU and the Central Committee of the Communist party of Kyrgyzstan sent excerpts from reports and numerous messages during the construction of the plant [1].

The geological conditions for the construction of the Tash-Kumyr semiconductor materials plant were very complex, gravel, sand, and seismological. Under the establishment and during the construction of the plant building, a large area of land is provided for the construction of heavy and defense dams. In 1985 alone, \$ 6 million was raised. 5.9 million cubic meters of bulldozing works were completed and more than 1 million cubic meters were mastered. the volume of production per cubic meter is 10 million US dollars. the soil in tons has been updated.

In 1982-85, 2.5 thousand workers and engineers worked in construction [6]. This year, 25 million US dollars will be raised for the production base. works in rubles at the installation facilities were built annually.

The Ministry of transport of the USSR built railway routes and bridges from the factory to institutions and organizations located in parallel in Kyrgyzstan. Having built not only industrial and production facilities, but also utilities, residential buildings, and cattle farms to provide food for factory workers [3].

A total of $\$ 79.2$ million was raised in 1982-85. capital investments in rubles have been mastered. Chairman of the Council of Ministers of the USSR L. V. Smirnov was the head of defense production issues in the USSR. Leonid Vasilyevich also provided great assistance in solving problems that arose during the construction period [4]. In Tash-Kumyr, with the participation of first Deputy Prime Minister T. Sarpashev, a Requiem rally is held in memory of those killed in the Aksy events of 2002:

"Dear Leonid Vasilevich!!!

As you know, the Ministry of non-ferrous metallurgy of the USSR is building a semiconductor materials plant in the city of Tash-Kumyr of the Kyrgyz SSR, in this connection, a total of 180 thousand rubles of trichloride per year, semi-crystalline silicon, quartz crucibles, singlelayer silicon epitaxial structures will be produced in the object group "100".

According to the national economy plan for 1985, the plant will be put into operation at the 1st place. The company is an energy well, consumes 1.3 billion kilowatt-hours of electricity per year, and also pays attention to creating the technical and economic foundations of the plant. Before putting the plant into operation, it is necessary to start work on the Tash-Kumyrskaya and wind hydroelectric power stations located in the immediate vicinity of the city.

Given the need for a comprehensive solution to the construction of the Tash-Kumyr semiconductor materials plant and the importance of reliable energy supply to the organization, we ask you, the Central Committee of the Communist party of Kyrgyzstan, to approve the list of priority state plans of the USSR and the USSR technical and economic project of the Tash-Kumyr HPP for 1982-83, the list of the wind HPP for 1983 and its renewable construction.”, On July 5, 
1982 (by order no. 65/06), Secretary of the Central Committee of the Kyrgyz Communist party, T. On.Usubaliev sent a letter.

This issue was resolved very quickly, from the position of Deputy Chairman of the state planning Committee of the USSR, Chairman of the Council of Ministers of the USSR N. I. O. dated September 28, 1982, № 26384.

The order of the Council of Ministers of the USSR dated July 15, 1982, No. Vp10932ss and dated August 30, 1982, No. PP-19361 was issued to start construction of electrical equipment and the Tash-Kumyr and Shamaldy-Say hydroelectric power stations of the Tash-Kumyr semiconductor materials plant.

Together with the Ministry of energy of the USSR and the Ministry of non-ferrous metallurgy of the USSR and the state planning Committee of the USSR, in order to provide the Tash-Kumyr plant with semiconductor materials, the construction dates for the Tash-Kumyr and Shamaldy-Say hydroelectric power stations were set [5]. In the first place, the Tash-Kumyr semiconductor materials plant is scheduled to be put into operation in 1985 , and in 1988 , the total capacity will be put into operation.

The plant's electrical equipment must be designed in conjunction with the Central Asian power system and worked out on the balance of the electric load capacity specified at the plant," he wrote. However, this enterprise did not reach its goal until some time after the collapse of the USSR due to the lack of industrial demand. The best experts on the construction of a semiconductor plant metallookandfeel V. V. G. Dubovitskiy, R. S. Deviatiarov and others. I built city structures.Fischer, L. Lamparter, N. Kabashnikov V. Dan'ko, V. Vasiliev, V. V. Doroshenko has made a great contribution.

\section{References:}

1. General provisions of Karimov, D Silicon revival of Tash-Kumyr. In Kyrgyzstan, "silicon valley" has been opened. D.-M.: Eksmo. 07.07.2009. www.24.kg.

2. Sideroff A. M. (1963). Industrial progress of the Kyrgyz. F.: School. 98.

3. Toigonbaev, J. (1982). W the training of qualified personnel of the working class of the Soviet Union: from the history of the formation of the modern working class. Toigonbaev. M .: Nauka, 126.

4. Usubaliev, T. U. (2006).-Kyrgyzstan is my heart T.VI. 2. B.: Sham, 826.

5. Economic basis of local self-government in the Kyrgyz Republic (2009). As amended By the laws of the Kyrgyz REPUBLIC dated February 14, 2008 N 14. Erkin LLP. 213.

6. Central Asia: a private view (2006). Bishkek, 498.

\section{Список литературы:}

1. Каримов Д. Производство поликристаллического кремния в Кыргызстане может получить государственную поддержку со стороны России // ИА «24.kg». 07.07.2009. https://24.kg/archive/ru/cis/52803-2009/07/07/115867.html/

2. Чормонов Б. Ш., Сидоров А. Ф. Промышленный прогресс в Киргизской ССР. Фрунзе: Киргосиздат. 1963.

3. Тойгонбаев Д. Подготовка квалифицированных рабочих кадров в республике. Фрунзе. 1969.

4. Usubaliev T. U. Kyrgyzstan is my heart.. B.: Sham, 2006. 826 c. 
5.Economic basis of local self-government in the Kyrgyz Republic [Text]: as amended By the laws of the Kyrgyz REPUBLIC dated February 14, 2008 N 14. Erkin LLP. 2009. 15 Jul. N213.

6. Central Asia: a private view. Bishkek, 2006. 498 p.

Работа поступила

в редакцию 14.01.2020 г.
Принята к публикациии

19.01.2020 2.

Ссылка для циитирования:

Zhumashova G., Arstanov S. Role and Place of Tash-Kumyr Semiconductor Materials Plant in Regional Development // Бюллетень науки и практики. 2020. Т. 6. №2. С. 329-333. https://doi.org/10.33619/2414-2948/51/41

Cite as (APA):

Zhumashova, G., \& Arstanov, S. (2020). Role and Place of Tash-Kumyr Semiconductor Materials Plant in Regional Development. Bulletin of Science and Practice, 6(2), 329-333. https://doi.org/10.33619/2414-2948/51/41 